\title{
Breast Cancer Subtypes Based on ER/PR and Her2 Expression: Comparison of Clinicopathologic Features and Survival
}

\author{
Adedayo A. Onitilo, MD, MSCR, FACP; Jessica M. Engel, MSN, FNP-BC; \\ Robert T. Greenlee, PhD; and Bickol N. Mukesh, PhD
}

\begin{abstract}
Objective: To compare the clinicopathologic features and survival in the four breast cancer subtypes defined by immunohistochemistry (IHC) expression of estrogen receptor (ER) or progesterone receptor (PR) and human epidermal growth factor receptor 2 (Her2): ER/PR+,Her2+; ER/PR+, Her2-; ER/PR-,Her2+; and ER/PR-,Her2-.
\end{abstract}

Methods: A 7-year retrospective study of I I 34 invasive breast cancer subjects. Clinical and pathologic features and survival of the four subtypes were compared.

Results: Using ER/PR+ and Her2- as a reference, ER/PR-,Her2- had the worst overall survival (hazard ratio, I.8; 95\% confidence interval $[\mathrm{Cl}]$, I.06-3.2) and the worst disease-free survival (hazard ratio, I.5; $95 \% \mathrm{Cl}, 0.8-3.0)$. In ER/PR+,Her2-, chemotherapy conferred significant overall and disease-free survival advantages. Subtype comparison revealed statistically significant differences in outcomes.

Conclusion: The triple negative subtype has the worst overall and disease free survival. Efforts should be directed at standardization of current testing methods and development of more reliable and reproducible testing.

Keywords: Breast cancer subtype; Survival; Treatment; Estrogen/progesterone receptor;

Human epidermal growth factor receptor 2 (HER2/neu); Immunohistochemistry; Triple negative

ver the last few decades there have been outstanding advances in breast cancer management leading to earlier detection of disease and the development of more effective treatments resulting in significant declines in breast cancer deaths and improved outcomes for women living with the disease. ${ }^{1,2}$ Breast cancer is no longer seen as a single disease but rather a multifaceted disease comprised of distinct biological subtypes with diverse natural history, presenting a varied spectrum of clinical, pathologic and molecular features with different prognostic and therapeutic implications. Consensus regarding the definitive prognostic/predictive analysis has yet to be reached, but significant progress continues to be made in the ongoing search for a specific, rigorous and reproducible method of identifying successful treatment algorithms utilizing biological markers.
Reprint Requests: Adedayo A. Onitilo, MD, MSCR, FACP, Marshfield Clinic Weston Center, 350I Cranberry Boulevard, Weston, WI 54476, Tel: 7I5-393-I400, Fax: 7I5-393-1399, Email: onitilo.adedayo@marshfieldclinic.org

Disclosure: Presented in part at the American Society of Clinical Oncology meeting Chicago, IL, May 30-June 3, 2008.
Recent attention has been directed singularly at molecular classifications of breast cancer.-11 While molecular and genetic testing is very elegant, prognostic and predictive, it is expensive and not yet widely available. Also, despite the prognostic information provided by the molecular test, current reports of assay results impart little specific guidance of response to targeted and proven therapy; for example, endocrine and trastuzumab therapy for tumors expressing estrogen receptor/progesterone receptor (ER/PR) or human epidermal growth factor receptor 2 (Her2) proteins, respectively. The immunohistochemistry (IHC) classification provides both therapeutic and prognostic information. 
In this study breast cancer is classified into four groups based on IHC profile ER/PR and Her2/neu expression, positive $(+)$ and/or negative (-). The groups are:

$$
\begin{aligned}
\text { ER/PR+,Her2+ }= & \text { ER+/PR+,Her2+; ER-/PR+,Her2+; } \\
& \text { ER+/PR-,Her2+ } \\
\text { - ER/PR+,Her2- = } & \text { ER+/PR+,Her2-; ER-/PR+,Her2-; } \\
& \text { ER+/PR-,Her2- } \\
\text { - ER/PR-,Her2+= ER-/PR-,Her2+ } & \text { ER/PR-,Her2- = ER-/PR-,Her2- }
\end{aligned}
$$

The IHC classification correlates well with intrinsic gene expression microarray categorization: $\mathrm{ER} / \mathrm{PR}+, \mathrm{Her} 2+$ with Luminal B; ER/PR+,Her2- with Luminal A; ER/PR-,Her2+ and ER/PR-,Her2- with triple negative/basal-like tumors. ${ }^{1}$ Apart from lending itself to subtype analyses of tumor when fresh tissue is not available, the IHC classification has prognostic and therapeutic implications, is inexpensive and readily available.

\section{SUBJECTS AND METHODS Study Population}

Female subjects $\geq 18$ years of age with invasive primary breast cancer (stage I-III) were electronically extracted from Marshfield Clinic/St. Joseph's Hospital Cancer Registry using ICD-O-3 codes C50.0-C50.9 with first date of diagnosis between January 1, 1998 and June 30, 2005. Marshfield Clinic is a large multi-specialty, multi-site group practice located throughout central and northern Wisconsin, partnered with St. Joseph's Hospital in Marshfield. Racial representation in the cancer registry during the study time period was 97.43\% White; 1.59\% unknown; 0.33\% American Indian, Aleutian, Eskimo; 0.25\% Asian Indian, Pakistani; and 0.04\% Black. The cancer registry identified 1767 breast cancer subjects of which 21 without follow-up data and 612 without ER/PR or Her2 data were excluded. Missing IHC results are attributable to the fact that Her2/neu testing was not common in the 1990s and early 2000s. It was not until late 2006 that the American Society of Clinical Oncology/College of American Pathologists recommended that Her2 testing be routinely performed in patients with a new diagnosis of invasive breast cancer. ${ }^{12}$

\section{Data Collection}

Approved by the Marshfield Clinic Institutional Review Board, Marshfield Clinic/St. Joseph's Hospital Cancer Registry was queried from January 1, 1998 to June 30, 2005 and provided the following data on each invasive breast cancer subject: age, gender, marital status, cancer site, tumor characteristics (morphology, grade and size, ER/PR and Her2 expression), stage of cancer at diagnosis, nodal disease status and location, margin status, specifics of treatment (doses, dates and duration of surgery, hormonal therapy, radiation, and chemotherapy), recurrence, date and location of recurrence, date and cause of death, and length of survival. Her2/neu expression not captured in registry reporting was abstracted as available from the medical record by investigators (AAO and JME).

\section{Resources}

Marshfield Clinic/St. Joseph's Hospital Cancer Registry

Marshfield Clinic/St. Joseph's Hospital Cancer Registry, initiated in 1960, is accredited by the American College of Surgeons Commission on Cancer and meets the Association of Community Cancer Center standards for cancer programs. Data from the cancer registry are submitted annually (1522 cases in 2005) to the National Cancer Database and the State of Wisconsin Cancer Reporting System. The registry has a 93.4\% 5-year follow-up rate, and an 89.8\% overall follow-up rate.

\section{Marshfield Clinic Electronic Medical Record}

The Marshfield Clinic electronic medical record system is an extensive archive of medical information including a full electronic medical chart; several enhanced clinical registries; procedures, insurance claims and lab results; and a file of more than 124 million patient diagnoses. A key feature of the electronic medical record system is the combined medical record which integrates data from all Marshfield Clinic facilities and affiliated hospitals. The combined medical record includes indices to all patient events and encounters within the Marshfield Clinic system of care, and can be accessed for all textual documentation such as office notes, operative reports and discharge summaries. The combined medical record also includes comprehensive lists of patient problems, diagnoses and procedures, current and past medication history, a variety of medication alerts, and online access to over a decade of laboratory and radiology results.

\section{Marshfield Laboratories}

Serving Marshfield Clinic and St. Joseph's Hospital, Marshfield Laboratories is a reference laboratory where IHC are performed centrally by experienced technicians and a dedicated pathologist who follows strict sample handling, processing and reporting protocols, thus ensuring the reliability of IHC testing and results.

\section{$E R / P R$}

$\mathrm{ER} / \mathrm{PR}$ results were obtained from the cancer registry having been processed in Marshfield Laboratories. The ER assay clone used was 1D5, the PR assay clone was PgR636 and the detection system was a polymer. IHC staining permits the detection and localization of ER/PR within sections from formalin-fixed, paraffin-embedded tissues. Staining of $>20 \%$ of tumor cell nuclei is considered positive. Staining of $5 \%$ to $19 \%$ of tumor cell nuclei is considered borderline. Staining of $<5 \%$ of tumor cell nuclei is considered negative (table 1 ). For the purpose of this study both borderline and overtly positive results were considered positive.

\section{Her2/neu}

Her $2 /$ neu results were obtained from the cancer registry as available or from the medical record. The clone used was a polyclonal (Her2 HercepTest Kit) and the detection system used was a polymer. The Food and Drug Administration has approved the reagents used in this IHC assay for assessment 
Table 1. ER/PR and Her2 scoring system and criteria

\section{The ER/PR scoring system and criteria}

Scoring system

0

$1+$

$2+$ to $3+$

Criteria

0

$1+$

$2+$

$3+$
Negative for receptor

Borderline - correlation with $\mathrm{DCC}^{*}$ method variable

Positive for receptor

$0 \%$ nuclear staining

$<10 \%$ nuclear staining

$10 \%$ to $75 \%$ nuclear staining

$>75 \%$ nuclear staining

\section{Her2 scoring system and criteria}

Scoring system

0

$1+$

$2+$

$3+$

Criteria

0

$1+$

$2+$

$3+$

\section{Negative \\ Negative \\ Weak positive \\ Positive}

Negative. No staining is observed, or membrane staining is $<10 \%$ of the tumor cells.

Negative. A faint /barely perceptible membrane staining is detected in $>10 \%$ of the tumor cells. The cells are only stained in part of the membrane.

Weak positive. A weak to moderate complete membrane staining is observed in $>10 \%$ of the tumor cells.

Positive. A strong complete membrane staining is observed in $>10 \%$ of the tumor cells.

* Deleted in colon cancer.

$\mathrm{ER}=$ estrogen receptor, Her2 = human epidermal growth factor receptor $2, \mathrm{PR}=$ progesterone receptor

of Her2 receptor status. Marshfield Laboratories considers a test result of 0 to $1+$ as negative and $3+$ as positive. For the current study a Her2/neu result of $2+$ is considered a negative result unless verified by fluorescent in-situ hybridization (FISH) (table 1). Fifty cases from the study were sent to Mayo Medical Laboratories where FISH was performed with evidence of Her2/neu gene amplification in 11 of the cases (18\%); thus, they are considered Her2 positive.

\section{STATISTICAL ANALYSIS}

Differences in subjects and tumor characteristics between the various breast cancer subtypes were analyzed using analysis of variance for continuous variables and chi-square test for categorical variables. The Kaplan-Meier product limit method was used to estimate the overall and disease-free survival. Ninety-five percent confidence intervals (CI) for the percentage surviving at a particular time were estimated using the logit transformation. Overall survival was measured from the date of diagnosis to the date of death from any cause. Disease-free survival was measured from the date of first definitive treatment to the date of first relapse or death from any cause. Survival times were censored at the dates of last contact for subjects who were lost to follow-up. Each breast cancer subtype was compared with the most common reference group of $\mathrm{ER} / \mathrm{PR}+, \mathrm{Her} 2-$ subtype.
Cox-proportional hazard model was used to estimate the hazard ratios and 95\% CI for overall and disease-free survival between the breast cancer subtypes adjusting for age, lymph node status and disease stage. S-plus statistical software was used for survival analysis and SAS 9.1 (SAS Institute, Cary, NC, USA) was used for all other analyses. A $P$-value of $<0.05$ was considered statistically significant.

\section{RESULTS}

Final analysis included 1134 invasive breast cancer subjects identified in the Marshfield Clinic/St. Joseph's Hospital Cancer Registry from January 1, 1998 to June 30, 2005. The mean age of all subjects was 62.7 years (SD, 13.8; range, 27.9 to 95.8 years). Baseline characteristics of subjects including tumor subtype are presented in table 2 . Of 1134 subjects, $116(10.2 \%)$ were ER/PR+,Her2+, 781 (68.9\%) were ER/PR+,Her2-, 85 (7.5\%) were ER/PR-,Her2+, and the remaining 152 (13.4\%) were classified as triple negative (table 2).

Differences in baseline characteristics between the four subtypes are presented in table 3 . Subjects with ER/PR+,Her2subtype were more likely to be older $(P<0.001)$, have early stage breast cancer $(P<0.001)$, present with small tumor $(P<0.001)$ and have a well/moderately differentiated histological grade $(P<0.001)$. They were less likely to be 
lymph node positive $(P<0.001)$, have a lobular tumor type $(P<0.001)$, and be treated with chemotherapy $(P<0.001)$.

Ninety-nine subjects (8.7\%) had recurrence and $140(12.3 \%)$ died during the follow-up period. The estimated median follow-up period for all subjects was 4.8 years (range, 3.2 months to 9.4 years). The 5-year overall survival for all subjects was $87.8 \%(95 \% \mathrm{CI}, 85.4-89.9)$ and the disease-free survival was $83.1 \%$ (95\% CI, 80.5-85.5). The 5-year overall and disease-free survival by tumor subtype, ER/PR status and
Her2 status is presented in table 4. Of the 99 subjects with recurrence, $45(45.5 \%)$ had local recurrence and the remaining had recurrences in bone (39.4\%), liver (22.2\%), lung (15.1\%), mediastinal lymph nodes $(10.1 \%)$, brain $(7.1 \%)$ and other sites $(11.1 \%)$ (table 5$)$. The age adjusted odds ratio for tumor characteristics associated with various subtype are presented in table 6 .

The Kaplan-Meier curve for overall and disease-free survival by tumor subtype is shown in figure 1. In the Cox regression

Table 2. Baseline characteristics

\begin{tabular}{|c|c|}
\hline Subject's characteristics & No. of subjects $(\%)(n=1134)$ \\
\hline $\begin{array}{l}\text { Tumor stage } \\
\text { I } \\
\text { II } \\
\text { III }\end{array}$ & $\begin{array}{c}639(56.4) \\
408(36.0) \\
87(7.7)\end{array}$ \\
\hline $\begin{array}{l}\text { Cancer type } \\
\text { Ductal } \\
\text { Lobular } \\
\text { Ductal and lobular } \\
\text { Inflammatory } \\
\text { Others }\end{array}$ & $\begin{array}{c}824(72.7) \\
137(12.1) \\
81(7.1) \\
15(1.3) \\
77(6.8)\end{array}$ \\
\hline $\begin{array}{l}\text { Histologic grade } \\
\text { Well differentiated } \\
\text { Moderately differentiated } \\
\text { Poorly differentiated } \\
\text { Missing }\end{array}$ & $\begin{array}{l}240(21.2) \\
435(38.4) \\
407(35.9) \\
52(4.6)\end{array}$ \\
\hline $\begin{array}{l}\text { Tumor size } \\
\qquad 2 \mathrm{~cm} \\
2.1 \text { to } 5 \mathrm{~cm} \\
>5 \mathrm{~cm} \\
\text { Missing }\end{array}$ & $\begin{array}{c}810(71.4) \\
262(23.1) \\
53(4.7) \\
9(0.8)\end{array}$ \\
\hline $\begin{array}{l}\text { Lymph node status } \\
\text { Positive } \\
\text { Negative } \\
\text { Not examined }\end{array}$ & $\begin{array}{c}351(31.0) \\
694(61.2) \\
89(7.8)\end{array}$ \\
\hline $\begin{array}{l}\text { Tumor subtypes } \\
\text { ER status positive } \\
\text { ER status negative } \\
\text { PR status positive } \\
\text { PR status negative } \\
\text { Her2 status positive } \\
\text { Her2 status negative } \\
\text { ER/PR+,Her2+ } \\
\text { ER/PR+,Her2- } \\
\text { ER/PR-,Her2+ } \\
\text { ER/PR-,Her2- }\end{array}$ & $\begin{array}{l}883(77.9) \\
251(22.1) \\
670(59.1) \\
464(40.9) \\
201(17.7) \\
933(82.3) \\
116(10.2) \\
781(68.9) \\
85(7.5) \\
152(13.4)\end{array}$ \\
\hline $\begin{array}{l}\text { Surgery } \\
\text { No surgery } \\
\text { Surgery }\end{array}$ & $\begin{array}{c}17(1.5) \\
1117(98.5)\end{array}$ \\
\hline $\begin{array}{l}\text { Chemotherapy } \\
\text { Radiotherapy } \\
\text { Hormone replacement therapy }\end{array}$ & $\begin{array}{l}519(45.8) \\
736(64.9) \\
792(69.8)\end{array}$ \\
\hline
\end{tabular}

$\mathrm{ER}=$ estrogen receptor, Her2 = human epidermal growth factor receptor $2, \mathrm{PR}=$ progesterone receptor, + = positive, - = negative. 
Table 3. Baseline characteristics by tumor subtype

\begin{tabular}{|c|c|c|c|c|c|}
\hline & $\begin{array}{c}\text { ER/PR+,Her2+ } \\
\quad(n=116)\end{array}$ & $\begin{array}{l}\text { ER/PR+,Her2- } \\
\quad(n=781)\end{array}$ & $\begin{array}{l}\text { ER/PR-,Her2+ } \\
\quad(n=85)\end{array}$ & $\begin{array}{c}\text { ER/PR-,Her2- } \\
\quad(n=152)\end{array}$ & $P$-value* \\
\hline Age (years) & $58.9 \pm 14.6$ & $64.4 \pm 13.2$ & $59.9 \pm 12.7$ & $58.1 \pm 14.7$ & $<0.001$ \\
\hline \multicolumn{6}{|l|}{ Tumor stage } \\
\hline 1 & $45(38.8 \%)$ & 496 (63.5\%) & $29(34.1 \%)$ & $69(45.4 \%)$ & \multirow[t]{3}{*}{$<0.001$} \\
\hline II & 59 (50.9\%) & 246 (31.5\%) & 37 (43.5\%) & $66(43.4 \%)$ & \\
\hline III & $12(10.3 \%)$ & $39(5.0 \%)$ & $19(22.4 \%)$ & $17(11.2 \%)$ & \\
\hline \multicolumn{6}{|l|}{ Cancer type } \\
\hline Ductal & 92 (79.3\%) & 536 (68.6\%) & $71(83.5 \%)$ & $125(82.2 \%)$ & \multirow[t]{5}{*}{$<0.001$} \\
\hline Lobular & $11(9.5 \%)$ & $117(15.0 \%)$ & $2(2.4 \%)$ & $7(4.6 \%)$ & \\
\hline Ductal and lobular & $7(6.0 \%)$ & $69(8.8 \%)$ & $1(1.2 \%)$ & $4(2.6 \%)$ & \\
\hline Inflammatory & $1(0.9 \%)$ & $1(0.1 \%)$ & $9(10.6 \%)$ & $4(2.6 \%)$ & \\
\hline Others & $5(4.3 \%)$ & $58(7.4 \%)$ & $2(2.4 \%)$ & 12 (7.9\%) & \\
\hline \multicolumn{6}{|l|}{ Histologic grade } \\
\hline Well differentiated & 7 (6.0\%) & $226(28.9 \%)$ & $1(1.2 \%)$ & $6(4.0 \%)$ & \multirow[t]{4}{*}{$<0.001$} \\
\hline Moderately differentiated & $48(41.4 \%)$ & $351(44.9 \%)$ & 17 (20.0\%) & 19 (12.5\%) & \\
\hline Poorly differentiated & 57 (49.1\%) & $168(21.5 \%)$ & $66(77.7 \%)$ & 116 (76.3\%) & \\
\hline Missing & $4(3.5 \%)$ & $36(4.6 \%)$ & $1(1.2 \%)$ & $11(7.2 \%)$ & \\
\hline \multicolumn{6}{|l|}{ Tumor size } \\
\hline$\leq 2 \mathrm{~cm}$ & 72 (62.1\%) & $616(78.9 \%)$ & 40 (47.1\%) & $82(54.0 \%)$ & \multirow[t]{4}{*}{$<0.001$} \\
\hline $2.1-5 \mathrm{~cm}$ & 39 (33.6\%) & $133(17.0 \%)$ & $34(40.0 \%)$ & $56(36.8 \%)$ & \\
\hline$>5 \mathrm{~cm}$ & $5(4.3 \%)$ & $30(3.8 \%)$ & 7 (8.2\%) & $11(7.2 \%)$ & \\
\hline Missing & - & $2(0.3 \%)$ & $4(4.7 \%)$ & $3(2.0 \%)$ & \\
\hline \multicolumn{6}{|l|}{ Lymph node status } \\
\hline Positive & $51(44.0 \%)$ & $216(27.7 \%)$ & 35 (41.2\%) & 49 (32.2\%) & \multirow[t]{3}{*}{$<0.001$} \\
\hline Negative & 57 (49.1\%) & 496 (63.5\%) & $44(51.8 \%)$ & 97 (63.8\%) & \\
\hline Not examined & $8(6.9 \%)$ & $69(8.8 \%)$ & $6(7.1 \%)$ & $6(4.0 \%)$ & \\
\hline \multicolumn{6}{|l|}{ Surgery } \\
\hline None & $2(1.7 \%)$ & $13(1.7 \%)$ & - & $2(1.3 \%)$ & \multirow[t]{2}{*}{0.73} \\
\hline Surgery & $114(98.3)$ & 768 (98.3) & 85 (100) & $150(98.7)$ & \\
\hline Chemotherapy & $79(68.1 \%)$ & 257 (32.9\%) & $71(83.5 \%)$ & $112(73.7 \%)$ & $<0.001$ \\
\hline Radiotherapy & $68(58.6 \%)$ & 504 (64.5\%) & $60(70.6 \%)$ & $104(68.4 \%)$ & .25 \\
\hline Hormone replacement therapy & 105 (90.5\%) & 647 (82.8\%) & 15 (17.7\%) & 25 (16.5\%) & $<0.001$ \\
\hline
\end{tabular}

* Missing values were excluded.

$\mathrm{ER}=$ estrogen receptor, Her2 $=$ human epidermal growth factor receptor $2, \mathrm{PR}=$ progesterone receptor, $+=$ positive, $-=$ negative.

analysis, subjects with the triple negative subtype, ER/PR-,Her2- had the worst overall survival (hazard ratio, $1.8 ; 95 \% \mathrm{CI}, 1.0-3.0$ ) and worst disease-free survival (hazard ratio, $1.5 ; 95 \% \mathrm{CI}, 0.8-3.0$ ) when compared with subjects with ER/PR+,Her2- subtype (table 7). Adjustment was made for age, stage, histological grade, chemotherapy treatment and lymph node status (table 7).

Among the 781 subjects with ER/PR+,Her2- subtype, 524 received no chemotherapy and 257 received chemotherapy. Those who received chemotherapy had significantly better overall (hazard ratio, $0.45 ; 95 \% \mathrm{CI}, 0.26-0.77 ; P=0.004$ ) and disease-free (hazard ratio, 54; 95\% CI, 0.34-0.86; $P=0.009$ ) survival benefits when compared with subjects who did not receive chemotherapy. No significant differences in overall and disease-free survival benefits were observed in other subtypes. This may be due to the small number of subjects in the other subtype groups.

\section{DISCUSSION}

This study confirmed breast cancer as a multifaceted disease comprised of distinct biological subtypes with diverse natural history which are increasingly recognized as presenting a varied spectrum of clinical, pathologic and molecular features with different prognostic and therapeutic implications. ${ }^{3}$ Our results reveal statistically significant differences in clinical and pathologic features and outcomes between subtypes. Using the most common subtype (ER/PR,$+ \mathrm{Her} 2-)$ as a reference, the triple negative subtype (ER/PR-,Her2-) had the worst overall survival (hazard ratio, 1.8; 95\% CI, 1.06-3.2), 
Table 4. Five-year overall and disease-free survival by tumor subtype, ER/PR and Her2 status

\begin{tabular}{|c|c|c|}
\hline Subtype & Overall survival (95\% Cl) & Disease-free survival $(95 \% \mathrm{Cl})$ \\
\hline \multicolumn{3}{|l|}{ Subtype } \\
\hline ER/PR+,Her2+ & $88.7 \%(79.2-94.1)$ & $83.2 \%(74.0-89.6)$ \\
\hline ER/PR+,Her2- & $90.3 \%(87.6-92.5)$ & $86.8 \%(83.8-89.4)$ \\
\hline ER/PR-,Her2+ & $78.8 \%(66.0-87.7)$ & $66.0 \%(53.9-76.3)$ \\
\hline ER/PR-,Her2- & $79.0 \%(70.8-85.3)$ & $73.5 \%(65.0-80.5)$ \\
\hline \multicolumn{3}{|l|}{ ER/PR status } \\
\hline $\mathrm{ER} / \mathrm{PR}+$ & $90.1 \%(87.5-92.2)$ & $86.4 \%(83.6-88.8)$ \\
\hline ER/PR- & $79.0 \%(72.4-84.4)$ & $70.8 \%(63.9-76.8)$ \\
\hline \multicolumn{3}{|l|}{ Her2 status } \\
\hline Positive & $84.6 \%(77.3-89.9)$ & $75.9 \%(68.6-81.9)$ \\
\hline Negative & $88.5 \%(85.9-90.6)$ & $84.7 \%(81.9-87.2)$ \\
\hline Overall & $87.8 \%(85.4-89.9)$ & $83.1 \%(80.5-85.5)$ \\
\hline
\end{tabular}

$\mathrm{Cl}=$ confidence interval, $\mathrm{ER}=$ estrogen receptor, Her2 = human epidermal growth factor receptor $2, \mathrm{PR}=$ progesterone receptor, $+=$ positive, $-=$ negative

Table 5. Recurrence site by breast cancer subtype

\begin{tabular}{|c|c|c|c|c|c|}
\hline & $\begin{array}{l}\text { No. of } \\
\text { recurrences } \\
(n=99)\end{array}$ & $\begin{array}{c}\text { ER/PR+,Her2+ } \\
(n=13)\end{array}$ & $\begin{array}{c}\text { ER/PR+,Her2- } \\
(n=41)\end{array}$ & $\begin{array}{c}\text { ER/PR-,Her2+ } \\
(n=21)\end{array}$ & $\begin{array}{c}\text { ER/PR-,Her2- } \\
\quad(n=24)\end{array}$ \\
\hline Local recurrence & $45(45.5 \%)$ & $5(38.5 \%)$ & $18(43.9 \%)$ & $13(61.9 \%)$ & $9(37.5 \%)$ \\
\hline Mediastinal lymph node & $10(10.1 \%)$ & $2(15.4 \%)$ & $2(4.9 \%)$ & $2(9.5 \%)$ & $4(16.7 \%)$ \\
\hline Abdomen/pelvis/soft/tissue & $2(2.0 \%)$ & - & $2(4.9 \%)$ & - & - \\
\hline Liver & $22(22.2 \%)$ & $5(38.5 \%)$ & $7(17.1 \%)$ & $6(28.6 \%)$ & $4(16.7 \%)$ \\
\hline Brain & $7(7.1 \%)$ & - & $3(7.3 \%)$ & $2(9.5 \%)$ & $2(8.3 \%)$ \\
\hline Lung & 15 (15.1\%) & $2(15.4 \%)$ & 7 (17.1\%) & 2 (9.5\%) & $4(16.7 \%)$ \\
\hline Bone & $39(39.4 \%)$ & $8(61.5 \%)$ & $19(16.3 \%)$ & $5(23.8 \%)$ & $7(29.2 \%)$ \\
\hline Effusion & $9(9.1 \%)$ & - & $4(9.8 \%)$ & - & $5(20.8 \%)$ \\
\hline
\end{tabular}

$\mathrm{ER}=$ estrogen receptor, Her2 = human epidermal growth factor receptor $2, \mathrm{PR}=$ progesterone receptor, $+=$ positive, $-=$ negative

Table 6. Age-adjusted odds ratios $(95 \% \mathrm{Cl})$ for tumor characteristics associated with subtypes as compared with reference group subtype ER/PR+,Her2-.

\begin{tabular}{|c|c|c|c|}
\hline Tumor characteristics & ER/PR+,Her2+ & ER/PR-,Her2+ & ER/PR-,Her2- \\
\hline Stage: III versus I and II & $1.6(0.7,3.5)$ & $5.4(2.5,11.8)$ & $2.2(1.0,4.9)$ \\
\hline Histologic grade: poorly differentiated versus well/moderately & $3.1(2.0,4.8)$ & $10.7(6.0,19.2)$ & $14.1(8.7,22.7)$ \\
\hline Lymph node: positive versus negative & $1.5(1.0,2.4)$ & $0.8(0.4,1.4)$ & $0.7(0.4,1.1)$ \\
\hline
\end{tabular}


Table 7. Hazard ratios $(95 \% \mathrm{Cl})$ for overall and disease-free survival by tumor subtypes after adjusting for age, stage, histological grade, chemotherapy treatment and lymph node

\begin{tabular}{|c|c|c|}
\hline Subtype & Overall survival & Disease-free survival \\
\hline \multicolumn{3}{|l|}{ Subtype } \\
\hline ER/PR+, Her2- & 1.00 & 1.00 \\
\hline ER/PR+, Her2+ & $1.03(0.52,2.05)$ & $1.03(0.52,2.05)$ \\
\hline ER/PR-, Her2+ & $1.34(0.69,2.62)$ & $1.54(0.80,2.96)$ \\
\hline ER/PR-, Her2- & $1.75(1.01,3.03)$ & $1.83(1.06,3.17)$ \\
\hline \multicolumn{3}{|l|}{ ER/PR status } \\
\hline ER/PR+ & 1.00 & 1.00 \\
\hline ER/PR- & $1.57(0.98,2.51)$ & $1.94(1.32,2.88)$ \\
\hline \multicolumn{3}{|l|}{ Her2 status } \\
\hline Positive & 1.00 & 1.00 \\
\hline Negative & $0.98(0.60,1.61)$ & $1.29(0.87,1.90)$ \\
\hline
\end{tabular}

A

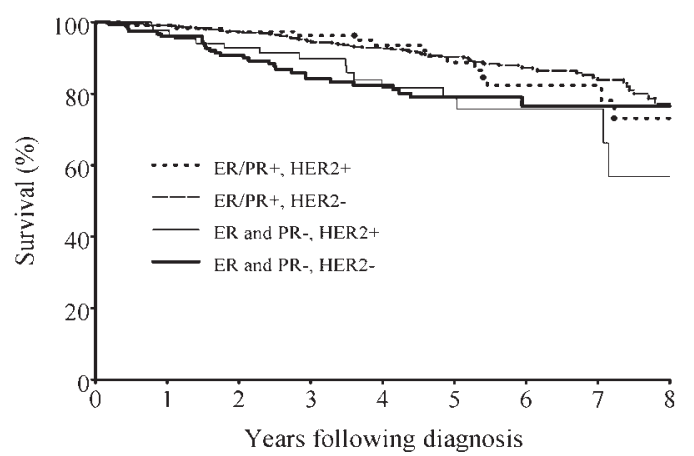

Number at risk $\begin{array}{llllllllll}\text { ER/PR+, HER2- } & 781 & 760 & 682 & 562 & 453 & 338 & 224 & 121 & 38\end{array}$ $\begin{array}{llllllllll}\text { ER and PR-, HER2+ } & 85 & 82 & 71 & 52 & 37 & 25 & 15 & 8 & 4\end{array}$ $\begin{array}{llllllllll}\text { ER and PR-, HER2- } & 152 & 144 & 126 & 93 & 78 & 54 & 31 & 18 & 8\end{array}$

B

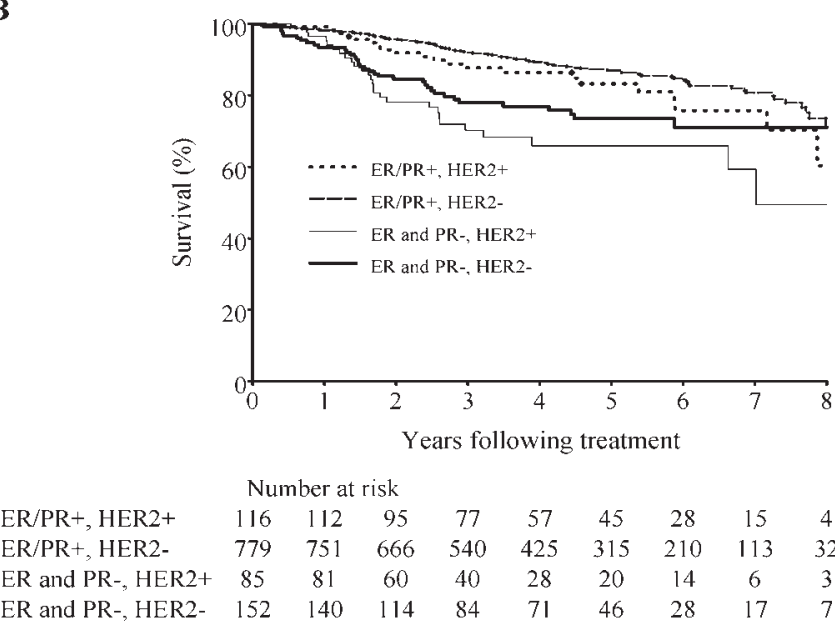

Figure 1. Overall (A) and disease-free (B) survival by tumor subtype. and worst disease-free survival (hazard ratio, $1.5 ; 95 \% \mathrm{CI}$, 0.8-3.0). These expected survival differences have meaningful implications for communication and care decisions between providers and their cancer patients. This subclassification should, however, be complemented with the many other important traditional prognostic variables for the individual such as age, tumor size, lymph node status, comorbidity, and adjuvant therapy.

IHC-based classification of both ER/PR and Her2 status provides prognostic and therapeutic information not achievable from either alone. Prior classifications separating breast cancer into one of two categories based on ER expression alone is less discriminatory in terms of prognosis, and the additional subclassification based on Her2 expression provides enhanced and important therapeutic guidance. Breast cancer has also sometimes been dichotomized into triple negativity or other. ${ }^{13}$ This classification is informative but simplistic and may be misleading by grouping the ER/PR-,Her2+ with ER/PR+,Her2+ and ER/PR+,Her2-. This was borne out in our results, where the ER/PR+,Her2+ had statistically equivalent survival to the referent $\mathrm{ER} / \mathrm{PR}+, \mathrm{Her} 2-$ subtype, and in practice, both types have better prognostic and therapeutic connotations. However, the ER/PR-,Her2+ point estimates were more similar to the triple negative values. Also, recent studies have suggested that within the $\mathrm{ER} / \mathrm{PR}+$ subtypes, the clinical and pathologic response to chemotherapy varies with the ER/PR+,Her2+ subtype defined by both hormone receptor and Her2 expression showing better response to chemotherapy $.^{13} \mathrm{ER} / \mathrm{PR}+, \mathrm{Her} 2+$ tumors virtually always have a high recurrence score. ${ }^{14}$ Recently it was shown in a retrospective analysis that $\mathrm{ER} / \mathrm{PR}+$,Her2- tumor may benefit less from taxanes in the adjuvant setting. ${ }^{15}$

We have classified breast cancer using IHC into 4 global subtypes out of the 8 possible subtypes commonly used by 
other authors. ${ }^{16}$ We believe this classification is practical, simple, informative, clinically useful, and quite discriminative between the subtypes. The other four groups will emerge if we differentiate based on $\mathrm{PR}$ expression $(\mathrm{ER}+/ \mathrm{PR}+\mathrm{vs}$. $\mathrm{ER}+/ \mathrm{PR}$ - tumors).

The independent prognostive and predictive role of PR expression irrespective of ER has been a subject of great controversy as demonstrated by the report from the ATAC (Arimidex, Tamoxifen, Alone or in Combination) adjuvant trial, a large worldwide trial comparing the efficacy of tamoxifen with that of the aromatase inhibitor anastrazole, showing overall that patients with $\mathrm{ER}+/ \mathrm{PR}+$ tumors had a lower recurrence rate than those with ER+/PR- tumors. ${ }^{17}$ The observation from the same study that patients with ER+/PRtumors respond nearly as well to anastrozole as those with $\mathrm{ER}+/ \mathrm{PR}+$ tumors suggests that the ER signaling pathway is functional in many $\mathrm{ER}+/ \mathrm{PR}$ - tumors, consistent with the well-known fact that the PR gene is regulated by the estrogen pathway. ${ }^{17}$ Also, the relative resistance by ER+/PR- tumors was not observed in the BIG 1-98 trial which is the largest study of an aromatase inhibitor as up-front adjuvant therapy for early breast cancer. ${ }^{18}$ Studies that have been classified as using more than 4 subtypes are plagued by these controversies and those inherent in small sample size and multiplicity of variables. ${ }^{19,20}$

Recent publications have shown that newer molecular classification of breast cancer also has important prognostic value. Subtyping breast cancer using microarrays for gene expression analysis is the best way to perform such molecular classification. However, most archived clinical specimens are not amenable to such analysis. Moreover, until recently when Oncotype DX and MammaPrint became commercially available, such assays were limited to research laboratories and, therefore, were not optimally available for commonplace clinical practice. The IHC-based classification systems are still useful in clinical practice, especially when fresh tissue is not available, and has been shown to correlate well with intrinsic classification using gene expression microarrays: ER/ $\mathrm{PR}+$,Her2+ with Luminal B; ER/PR+,Her2- with Luminal A; ER/PR-,Her2+ (ER-/Her2+) and ER/PR-,Her2- with triple negative/basal-like tumors. ${ }^{3,13}$ It is worth noting that the reliability of the ER/PR and Her2 testing is imperfect. There is substantial intralaboratory and interlaboratory variation in ER results because fixation, antigen retrieval, and staining methods may differ among laboratories. ${ }^{21-23}$ Substantial discordance among Her2 results generated in different laboratories from the same specimen has also been reported. ${ }^{12,21,24}$ For this classification to be more helpful, ongoing efforts ${ }^{12}$ should also be directed at standardization of current testing and development of more reliable and reproducible testing for ER/PR and Her2/ neu expression. ${ }^{12,21-24}$

In our current analysis we have not considered the semi-quantitative information from IHC in terms of ER/PR or Her2 levels of expression on clinical outcomes largely because we do not have adequate sample for such analysis.
We believe such subsetting within the subtypes may be unreliable, with regards to the message highlighted in this study, due to inadequate sample size.

This study of a predominantly Caucasian population reports the distribution of subtypes as different from that seen in a predominantly African American population where ER/PR-,Her2- is more prevalent (39\% premenopausal versus 14\% postmenopausal African American women versus 16\% non-African American women of all ages). ${ }^{3}$ Also of note, $80 \%$ of our subjects are ER+ accounting in part for the overall 5-year survival of $87.8 \%(95 \% \mathrm{CI}, 85.4-89.9)$ and 5-year disease-free survival of $83.1 \%(95 \% \mathrm{CI}, 80.5-85.5)$. A large percentage of our patients demonstrate favorable features such as small tumor size $(<2 \mathrm{~cm} ; 71 \%)$, negative nodal status $(61 \%)$, and low to moderate histologic grade (59\%).

An investigation of all subgroups showed benefit from chemotherapy, but after controlling for age, tumor size, and lymph node status, the sample size was not sufficient to make a strong assertion except in the ER/PR+,Her2- subgroup. In the ER/PR+,Her2- subgroup (781 subjects), 524 patients did not receive chemotherapy and 257 patients did receive chemotherapy. Chemotherapy conferred overall and disease-free survival advantages $(P=0.003$ and $P=0.009$, respectively).

This study supports other studies ${ }^{3,13,25}$ which have shown both the triple negative and Her2+/ER- subtypes to have poorer clinical, pathologic and molecular prognoses. The triple negative group has the worst overall and disease-free survival. For the triple negative group the disease-free survival curve tends to plateau after the second and third year, but the curve continues downward for the Her2+/ER-. In 2008, tumor-expressed proteins, such as ER and Her2, play an increasingly important role in determining breast cancer treatment. For example, women with ER+ breast cancer typically receive endocrine therapy (tamoxifen or aromatase inhibitors) and women with Her2+ breast cancer may receive anti-Her2 (trastuzumab [Herceptin] and lapatinib [Tykerb]). It is reasonable to assume that trastuzumab and lapatinib will shift the Her2+ curve upward (Her2+/ER-). We lack targeted therapies for triple negative breast cancer and this continues to direct the focus of ongoing research. ${ }^{26-28}$

Despite the enormous effort and funding channeled towards molecular diagnostics, there is still relevance for IHC, especially when performed by inexperienced centers. Although molecular arrays have been around for approximately a decade, new therapeutic target proteins are not being identified, thus the predictive value of the assays are relatively global or limited to known targets such as ER/PR protein or the Her2 gene. Also, despite multiple and different gene sets used in most of the molecular testing, there is significant agreement in the outcome predictions for individual patients by these tests, ${ }^{14}$ suggesting that they are probably tracking a common set of biologic phenotypes which are heavily 
weighted toward ER/PR and Her2 gene pathways. Finally, the superiority of molecular technology over IHC testing is theoretical and based on the premise that molecular technology provides quantization and reproducibility. This presumptive theory is the basis for some ongoing studies but is yet to be proven.

\section{CONCLUSIONS}

Our study showed the triple negative subtype (ER/PR-,Her2-) has the worst overall and disease-free survival compared to the other subtypes. Further confirmatory studies are necessary to refine IHC classification. We support IHC classification as a clinical tool as ER/PR and Her2 testing is widely available at a reasonable cost, is a clinically-used, therapeutically informative classification of breast cancer based on immunophenotype/biologic phenotypes, and is prognostic as well as somewhat predictive. Additional ongoing efforts $^{12}$ should be directed at standardization of current testing methods and development of more reliable and reproducible testing.

\section{ACKNOWLEDGMENTS}

The authors thank Marshfield Clinic Research Foundation for its support through the assistance of Anne Nikolai and Alice Stargardt in the preparation of this manuscript. We also appreciate the editorial comments of Dr. William Hocking.

\section{REFERENCES}

1. Glass AG, Lacey JV Jr, Carreon JD, Hoover RN. Breast cancer incidence, 1980-2006: combined roles of menopausal hormone therapy, screening mammography, and estrogen receptor status. J Natl Cancer Inst 2007;99:1152-1161.

2. Ravdin PM, Cronin KA, Howlader N, Berg CD, Chlebowski RT, Feuer EJ, Edwards BK, Berry DA. The decrease in breast-cancer incidence in 2003 in the United States. N Engl J Med 2007;356:1670-1674

3. Carey LA, Perou CM, Livasy CA, Dressler LG, Cowan D, Conway K, Karaca G, Troester MA, Tse CK, Edmiston S, Deming SL, Geradts J, Cheang MC, Nielsen TO, Moorman PG, Earp HS, Millikan RC. Race, breast cancer subtypes, and survival in the Carolina Breast Cancer Study. JAMA 2006;295:2492-2502.

4. Chang HY, Nuyten DS, Sneddon JB, Hastie T, Tibshirani R, Sørlie T, Dai H, He YD, van't Veer LJ, Bartelink H, van de Rijn M, Brown PO, van de Vijver MJ. Robustness, scalability, and integration of a wound-response gene expression signature in predicting breast cancer survival. Proc Natl Acad Sci U S A 2005;102:3738-3743.

5. Dolled-Filhart M, Rydén L, Cregger M, Jirström K, Harigopal M, Camp RL, Rimm DL. Classification of breast cancer using genetic algorithms and tissue microarrays. Clin Cancer Res 2006;12:6459-6468.

6. Liu R, Wang X, Chen GY, Dalerba P, Gurney A, Hoey T, Sherlock G, Lewicki J, Shedden K, Clarke MF. The prognostic role of a gene signature from tumorigenic breast-cancer cells. N Engl J Med 2007;356:217-226.

7. Paik S, Shak S, Tang G, Kim C, Baker J, Cronin M, Baehner FL, Walker MG, Watson D, Park T, Hiller W, Fisher ER, Wickerham DL, Bryant J, Wolmark N. A multigene assay to predict recurrence of tamoxifen-treated, node-negative breast cancer. N Engl J Med 2004;351:2817-2826.
8. Sørlie T, Tibshirani R, Parker J, Hastie T, Marron JS, Nobel A, Deng S, Johnsen H, Pesich R, Geisler S, Demeter J, Perou CM, Lønning PE, Brown PO, Børresen-Dale AL, Botstein D. Repeated observation of breast tumor subtypes in independent gene expression data sets. Proc Natl Acad Sci U S A 2003;100:8418-8423.

9. Sørlie T, Perou CM, Fan C, Geisler S, Aas T, Nobel A, Anker G, Akslen LA, Botstein D, Børresen-Dale AL, Lønning PE. Gene expression profiles do not consistently predict the clinical treatment response in locally advanced breast cancer. Mol Cancer Ther 2006;5:2914-2918.

10. van de Vijver MJ, He YD, van't Veer LJ, Dai H, Hart AA, Voskuil DW, Schreiber GJ, Peterse JL, Roberts C, Marton MJ, Parrish M, Atsma D, Witteveen A, Glas A, Delahaye L, van der Velde T, Bartelink H, Rodenhuis S, Rutgers ET, Friend SH, Bernards R. A gene-expression signature as a predictor of survival in breast cancer. N Engl J Med 2002;347:1999-2009.

11. Wang Y, Klijn JG, Zhang Y, Sieuwerts AM, Look MP, Yang F, Talantov D, Timmermans M, Meijer-van Gelder ME, Yu J, Jatkoe T, Berns EM, Atkins D, Foekens JA. Gene-expression profiles to predict distant metastasis of lymph-node-negative primary breast cancer. Lancet 2005;365:671-679.

12. Wolff AC, Hammond ME, Schwartz JN, Hagerty KL, Allred DC, Cote RJ, Dowsett M, Fitzgibbons PL, Hanna WM, Langer A, McShane LM, Paik S, Pegram MD, Perez EA, Press MF, Rhodes A, Sturgeon C, Taube SE, Tubbs R, Vance GH, van de Vijver M, Wheeler TM, Hayes DF; American Society of Clinical Oncology; College of American Pathologists. American Society of Clinical Oncology/College of American Pathologists guideline recommendations for human epidermal growth factor receptor 2 testing in breast cancer. J Clin Oncol 2007;25:118-145.

13. Carey LA, Dees EC, Sawyer L, Gatti L, Moore DT, Collichio F, Ollila DW, Sartor CI, Graham ML, Perou CM. The triple negative paradox: primary tumor chemosensitivity of breast cancer subtypes. Clin Cancer Res 2007;13:2329-2334.

14. Fan C, Oh DS, Wessels L, Weigelt B, Nuyten DS, Nobel AB, van't Veer LJ, Perou CM. Concordance among gene-expression-based predictors for breast cancer. N Engl J Med 2006;355:560-569.

15. Hayes DF, Thor AD, Dressler LG, Weaver D, Edgerton S, Cowan D, Broadwater G, Goldstein LJ, Martino S, Ingle JN, Henderson IC, Norton L, Winer EP, Hudis CA, Ellis MJ, Berry DA; Cancer and Leukemia Group B (CALGB) Investigators. HER2 and response to paclitaxel in node-positive breast cancer. N Engl J Med 2007; 357:1496-1506.

16. Nguyen PL, Taghian AG, Katz MS, Niemierko A, Abi Raad RF, Boon WL, Bellon JR, Wong JS, Smith BL, Harris JR. Breast cancer subtype approximated by estrogen receptor, progesterone receptor, and HER-2 is associated with local and distant recurrence after breast-conserving therapy. J Clin Oncol 2008;26:2373-23788.

17. Howell A, Cuzick J, Baum M, Buzdar A, Dowsett M, Forbes JF, Hoctin-Boes G, Houghton J, Locker GY, Tobias JS; ATAC Trialists' Group. Results of the ATAC (Arimidex, Tamoxifen, Alone or in Combination) trial after completion of 5 years' adjuvant treatment for breast cancer. Lancet 2005;365:60-62.

18. Coates AS, Keshaviah A, Thürlimann B, Mouridsen H, Mauriac L, Forbes JF, Paridaens R, Castiglione-Gertsch M, Gelber RD, Colleoni M, Láng I, Del Mastro L, Smith I, Chirgwin J, Nogaret JM, Pienkowski T, Wardley A, Jakobsen EH, Price KN, Goldhirsch A. Five years of letrozole compared with tamoxifen as initial adjuvant therapy for postmenopausal women with endocrine-responsive early breast cancer: update of study BIG 1-98. J Clin Oncol 2007;25:486-492. 
19. Francis G, Beadle G, Thomas S, Mengersen K, Stein S. Evaluation of oestrogen and progesterone receptor status in HER-2 positive breast carcinomas and correlation with outcome. Pathology 2006;38:391-398.

20. Brouckaert O, Pintens S, Van Belle V, Van Huffel S, Camerlynck E, Amant F, Leunen K, Smeets A, Berteloot P, Van Limbergen E, Decock J, Hendrickx W, Weltens C, Van den Bogaert W, Vanden Bempt I, Drijkoningen M, Paridaens R, Wildiers H, Vergote I, Christiaens MR, Neven P. Short-term outcome of primary operated early breast cancer by hormone and HER-2 receptors. Breast Cancer Res Treat 2009;115:349-358.

21. Rhodes A, Jasani B, Barnes DM, Bobrow LG, Miller KD. Reliability of immunohistochemical demonstration of oestrogen receptors in routine practice: interlaboratory variance in the sensitivity of detection and evaluation of scoring systems. J Clin Pathol 2000;53:125-130.

22. Goldstein NS, Ferkowicz M, Odish E, Mani A, Hastah F. Minimum formalin fixation time for consistent estrogen receptor immunohistochemical staining of invasive breast carcinoma. Am J Clin Pathol 2003;120:86-92.

23. Rüdiger T, Höfler H, Kreipe HH, Nizze H, Pfeifer U, Stein H, Dallenbach FE, Fischer HP, Mengel M, von Wasielewski R, Müller-Hermelink HK. Quality assurance in immunohistochemistry: results of an interlaboratory trial involving 172 pathologists. Am J Surg Pathol 2002; 26:873-882.

24. Roche PC, Suman VJ, Jenkins RB, Davidson NE, Martino S, Kaufman PA, Addo FK, Murphy B, Ingle JN, Perez EA. Concordance between local and central laboratory HER2 testing in the breast intergroup trial N9831. J Natl Cancer Inst 2002;94:855-857.

25. Dent R, Trudeau M, Pritchard KI, Hanna WM, Kahn HK, Sawka CA, Lickley LA, Rawlinson E, Sun P, Narod SA. Triple-negative breast cancer: clinical features and patterns of recurrence. Clin Cancer Res 2007;13:4429-4434.

26. Piccart-Gebhart MJ, Procter M, Leyland-Jones B, Goldhirsch A, Untch M, Smith I, Gianni L, Baselga J, Bell R, Jackisch C, Cameron D, Dowsett M, Barrios CH, Steger G, Huang CS, Andersson M, Inbar M, Lichinitser M, Láng I, Nitz U, Iwata H, Thomssen C, Lohrisch C, Suter TM, Rüschoff J, Suto T, Greatorex V, Ward C, Straehle C, McFadden E, Dolci MS, Gelber RD; Herceptin Adjuvant (HERA) Trial Study Team. Trastuzumab after adjuvant chemotherapy in HER2positive breast cancer. N Engl J Med 2005;353:1659-1672.

27. Romond EH, Perez EA, Bryant J, Suman VJ, Geyer CE Jr, Davidson NE, Tan-Chiu E, Martino S, Paik S, Kaufman PA, Swain SM, Pisansky TM, Fehrenbacher L, Kutteh LA, Vogel VG, Visscher DW, Yothers G, Jenkins RB, Brown AM, Dakhil SR, Mamounas EP, Lingle WL, Klein PM, Ingle JN, Wolmark N. Trastuzumab plus adjuvant chemotherapy for operable HER2-positive breast cancer. N Engl J Med 2005;353:1673-1684.

28. Slamon D, Eiermann W, Robert N, Pienkowski T, Martin M, Pawlicki M, Chan M, Smylie M, Liu M, Falkson C, Pinter T, Fornander T, Shiftan T, Valero V, Mackey J, Tabah-Fisch I, Buyse M, Lindsay MA, Riva A, Bee V, Pegram M, Press $\mathrm{M}$, Crown J, on behalf of the BCIRG 006 Investigators. Phase III randomized trial comparing doxorubicin and cyclophosphamide followed by docetaxel $(\mathrm{AC} \rightarrow \mathrm{T})$ with doxorubicin and cyclophosphamide followed by docetaxel and trastuzumab $(\mathrm{AC} \rightarrow \mathrm{TH})$ with docetaxel, carboplatin and trastuzumab (TCH) in HER2 positive early breast cancer patients: BCIRG 006 study. San Antonio (TX): San Antonio Breast Cancer Symposium; 2005. [abstract] Available at: http://www.abstracts2view.com/sabcs05/view. php?nu=SABCS05L_921\&terms $=$. Accessed January 18, 2008.
AUTHOR AFFILIATIONS

Adedayo A. Onitilo, MD, MSCR, FACP

Department of Hematology/Oncology

Marshfield Clinic Weston Center

3501 Cranberry Blvd

Weston, Wisconsin 54401

Jessica M. Engel, MSN, FNP-BC

Department of Hematology/Oncology

Marshfield Clinic

1000 North Oak Avenue

Marshfield, Wisconsin 54449

Robert T. Greenlee, PhD

Epidemiology Research Center

Marshfield Clinic Research Foundation

1000 North Oak Avenue

Marshfield, Wisconsin 54449

Bickol N. Mukesh, PhD

Biomedical Informatics Research Center

Marshfield Clinic Research Foundation

1000 North Oak Avenue

Marshfield, Wisconsin 54449

Current affiliation:

Alcon Laboratories, Inc.

6201 South Freeway

Fort Worth, TX 76134 